\title{
Bid-Ask Spread on Earnings Management with Good Corporate Governance as Moderation Variables: Banking Sector in Indonesia
}

\author{
IMAM GHOZALI, SUGENG WAHYUDI, HERSUGONDO \\ Department Management, Faculty of Economics and Business, Diponegoro University, INDONESIA \\ ANTON SATRIA PRABUWONO \\ Faculty of Computing and Information Technology, King Abdul Aziz University, Saudi Arabia \\ IMANG DAPIT PAMUNGKAS \\ Department of Accounting, Faculty of Economics and Business, Dian Nuswantoro University, \\ INDONESIA
}

\begin{abstract}
This study aims to determine the effect of the bid-ask spread on earnings management and good corporate governance (GCG) as moderating variables. The research method used is a quantitatively descriptive research method that aims to examine the effect of bid-ask spread on the earning management moderated by GCG. The population in this study are banking companies listed on the Indonesia Stock Exchange (IDX). In this study, found that the sample was obtained using purposive sampling. So, the model in this study with 102 total samples. The analysis tool used is Warp-PLS 6.0. This study shows that the bid-ask spread significantly influences on earnings management of banking companies on the IDX in the years 2014-2020. GCG cannot the effects of bid-ask spreads on the earnings management of banking companies on the IDX in the years 20142020.
\end{abstract}

\section{Key-Words: - Bid-Ask Spread, Earnings Management, Good Corporate Governance}

Received: June 17, 2021. Revised: December 21, 2021. Accepted: January 16, 2022. Published: January 18, 2022.

\section{Introduction}

Financial statements are an essential tool and source of information used by outside parties to assess the company's performance. The information provided must be relevant and reliable to describe the actual financial position of a company. Earning is one of the primary goals of starting a business. This is the main factor that leads managers to take many avenues, such as earning management, to increase their company's bottom line [1]. Management always tries to perform well. The goal is also to produce good financial reports. If management fails to do this, it usually changes the financial statements by increasing or decreasing profits, known as earning management [2]. In financial accounting, earning management is still controversial. According to [3], earning management is a deviation due to profit figures in the annual financial statements.

Earning management arises from agency problems, namely from the conflicts of interest between owners and management. Earning management measures are based on two behaviour of managers, namely opportunistic behaviour and efficient contract drafting. Both can affect the results reported in the annual financial statements, which can mislead users of annual financial statements in making economic decisions. The part of financial statements that shareholders often use to make investment decisions is income information. Because profit is an indicator that is widely used to measure the success of the company's operational performance, by agency theory, earnings management practices are reflected in the opportunistic behavior of management. [4]. Agency theory explains that managers can act opportunistically when the company performs poorly by increasing book profit to hide poor performance. Conversely, managers can work opportunistically by lowering their book profit to delay exemplary implementation [5].

There have been many cases of revenue management in several banking companies, particularly PT Bank Mandiri Syariah (BSM.) in 2018. The subsidiary of PT Bank Mandiri Tbk has launched a fictional action worth Rs.1.1 trillion. The Indonesian Anti-Corruption Society (MAKI) assesses whether the money disbursed is not used by submitting a financing proposal from the debtor so that it is called fictitious. In addition, the question of the disbursement of financing is used in selfinterest. Gave the allegedly fictional funding to 
several companies such as PT A worth Rp 21.22 billion, PT GAI Rp 6.92 billion, PT QP Rp 3.49 billion, PT EEI Rp 9.52 billion, PT DSM Rp 7.64 billion, PT BBL Rp 34.53 billion, and PT MRP Rp 17.42 billion [6]. The following case earning management at PT Bank Bukopin has proven inaccurate year-end information over the past five years. On April 25, 2018, it was determined that PT Bank Bukopin had corrected its 2016 annual financial statements. 1.08 trillion in Rp. 183.53 billion PT Bank Bukopin arranged several credit card business outcomes unusually, leading to significant information changes [7].

One of the causes of earnings management is the bid-ask spread which becomes information asymmetry, namely the distance between the lowest offer price (bid) and the highest ask price (ask) [8]. Information asymmetry occurs when investors and management have different information that causes investors to lose their decision-making. Studies by [3] show that the bid-ask spread positively affects earning management. Suppose the spread is large, the greater the chance for managers to take action to control earnings. Large spreads indicate the imbalance in information ownership between external parties and internal parties. Managers efficiently manage results out of their interest or the urge to perform well because outside parties do not know their state and prospects. These results agree [9] that the asymmetry of information with bid-ask spread positively affects earning management. However, the results from the research by [2] show that the bid-ask spread does not affect earnings management.

There are several differences in the study results, such as [10], [11] study, which shows that the bidask spread positively affects earnings management. Meanwhile, research by [2] indicates a negative impact between bid-ask spreads on earnings management. Research by [11] that the bid-ask spread has a positive and significant effect on earnings management practices because the activities of the managers are not precisely known to the investors. However, the results of this study are not identical to the research by [12]. The results of this study contradict [9], [13]-[16] that information asymmetry does not have a significant impact on earning management.

GCG is one of the company's regulatory and control systems to create added value for the stakeholders [17]. The GCG concept essentially requires transparency for all of this information to protect all interests of the principal [18]. Implementing corporate governance that is not maximized will lead to information asymmetry conditions that will cause agents to take measures to control earnings. The corporate governance mechanism can produce financial reports in which the description contains profit information. Companies need to implement a better monitoring and control system to reduce earning management practices [19]. GCG is a way to ensure that capital owners are confident about getting the returns on their investments. GCG also aims to control the relationship between clients to minimize errors [20].

[3] shows that GCG can weaken the effect of bid-ask spreads on earnings management practices. Based on the research results by [16], it is proven that GCG can mitigate the impact of information asymmetry on earnings management. However, in contrast to the effects of [8], it shows that GCG cannot minimize the impact of bid-ask spreads on earnings management. The results of these studies indicate that there are inconsistencies, it requires further testing. Novelty in this study adds Good Corporate Governance as moderation variables to the relationship between bid-ask spread on earnings management. This study aims to determine the effect of the bid-ask spread on earnings management. The benefits of this research are expected to be used to increase knowledge, broaden insight, and complement previous research. Furthermore, it can be used as input and as additional reference material for investors. Investors are advised to pay attention to the supporting factors, namely, to continue implementing better corporate governance in the company every year before investing. The next step is to find out whether GCG, as a moderating variable, can strengthen or weaken the impact of bid-ask spreads on earnings management.

\section{Literature Review}

\subsection{Agency Theory}

According to agency theory, agents and shareholders have different interests because of the various goals of the two [4]. The owner of the company strives for a high return on investment; the agent, on the other hand, strives for maximum personal compensation from his performance, measured by the company's profit. Therefore, the management tries to manipulate the actual profit situation of the company to get maximum compensation. This is an opportunity for the administration to do earning management. Information asymmetry can occur in uneven communication between agents and principals because agents exhibit dysfunctional behavior. 
Agency theory states that an oversight mechanism can reduce conflicts between agents and principals. In contrast to GCG, it can reconcile various interests that exist in the company. The existence of oversight will prevent management from taking action. This can be disadvantageous for shareholders, so that can reduce costs or losses due to management measures.

\subsection{Earning Management}

Earning control is a form of variance that affects the profit figures in the financial statements. According to [21], an information imbalance can create opportunities for earning management. Earning management can be done through provisioning policies or real-world activities [22]. Earning control measures show that the reported income does not match the actual economic situation, so the reported income can be higher or lower. Results reports that do not describe economic conditions/positions are only made at the request of management so that management appears to be performing well. According to [23], "Earning management is the activity of executives who intend to influence and intervene in the company's annual financial statements." If the manager carries out the earning management, that is, decides on the method/system and accounting standard used. This corresponds to the company's needs presented in the financial statements; this step does not include cases of fraud and management errors. However, suppose during the action to amend the financial statements, the manager did it only for his benefit, taking advantage of the client's misunderstanding regarding the information about the real state of the company. In that case, this revenue management action is known as a fraud by the manager. Management aims to obscure the users' understanding of financial statements. Conceptually, efforts are made to cover up, delay disclosure, and change any financial or information from managers to mislead interested parties in the company's financial statements and terms and conditions and performance. The more information the company has in the hands of the managers than the shareholders. More and more managers will have the opportunity to operate earning management.

\subsection{Bid-Ask Spread}

[24] explains that the bid-ask spread is a function of three cost components: warehousing, order fulfillment, and asymmetric information. [25] emphasize that studies of transaction costs/proximity costs should distinguish trader spreads from market spreads. Furthermore, [26] stated that the trader's spread of a stock is the difference between the offer price and the offer price, which is determined individually by the trader when the shares are traded. The market spread is the difference between the highest bid price and the lowest ask price of traders trading stocks together. Thus, market spreads can be smaller when compared to dealer spreads.

This is one of the factors that investors consider when deciding whether to hold or sell the stocks. According to [27] that the bid-ask spread is a function of transaction costs. Assets with larger spaces are projected to generate higher expected returns, so investors expect a long holding period. Bid-ask spread dealers and brokers are often used by investors when buying and selling stocks or securities. The traders and brokers sell supplies to investors at the asking price. If the investor already owns the store and wants to sell it, the dealer or broker will buy the stock at the bid price. The difference between the asking price and the bid price is known as the spread. The bid price is the highest price offered, while the lowest priced one is willing to accept to sell the stock is called the asking price. The larger the spread, the higher the probability of controlling earnings. If the spread is large, the stock's liquidity will be less. This is because the demand for supplies decreases, so the liquidity of stocks falls. The higher the bid-ask spread, the higher the likelihood of earning management practices.

\subsection{Good Corporate Governance}

According to [20], corporate governance is a system that regulates, controls, and monitors business control processes. GCG is a concept that can increase economic efficiency and involves multiple connections between company executives, directors, shareholders, government, employees, and other corporate actors [28]. Corporate governance also provides opportunities for setting corporate goals and making decisions about performance monitoring techniques. One of the appropriate steps to monitor contractual issues and constraints on opportunistic management behaviour is corporate governance [29]. Regarding the agency issue, corporate governance, which has a conceptual meaning based on agency theory, is expected to help give investors confidence/reassurance that investors are getting a return on the money/capital they purchase that you invested or invested. 


\subsection{The Effect of the Bid-Ask Spread on Earning Management}

Some researchers have found that bid-ask spreads can affect earnings management. [2], [10] show that the bid-ask spread positively affects earnings management when the spread is large, the more opportunities for managers to conduct earning management. Financial reports are the most important and are needed to reach an agreement on the investment in the company by outside parties. The signaling theory states that there is an imbalance between internal and external parties. Investors do not have that information; it leads managers to conduct revenue management and give misleading signals to investors [30]. Studies [3] show that the bid-ask spread positively affects earning management. When the space is ample, the more excellent the opportunity for managers to conduct earning management. The results of large spreads evidence the imbalance in information ownership between internal and external parties. Managers efficiently manage earnings out of personal interests or want to perform well when outside parties are unaware of the company's state.

In further studies, the information asymmetry using the bid-ask spread harms earning management [8]. Every company does not desire information asymmetry as it can influence the development of earning management measures. The information asymmetry is indicated by the difference to the bidask, measured by the spread. Then the investigation of information asymmetry carried out by Wiharno \& Rahayu, (2018), calculated using the bid-ask distance, has a positive effect on earnings management. Similarly, studying the information asymmetry represented by the bid-ask spread positively impacts earning management [9].

H1: Bid-ask spread has a positive effect on earning management

\subsection{The Effect of Good Corporate Governance in Moderating the Relationship between Bid-Ask Spread on Earnings Management}

GCG will encourage transparency of financial documents and reports as well as practical and efficient supervision. The existence of transparency in the reporting of financial statements allows owners to monitor managers' performance, thereby minimizing earnings management practices. Manager intervention in preparing financial statements to increase personal profit is known as earnings management. [21] notes that corporate governance can reduce the practice of earnings management. In companies with large bid-ask spreads, internal parties have more information than external parties in creating earnings management opportunities. If the company has GCG, the supervision is tighter, so it can eliminate earnings management practices. The existence of GCG is expected to weaken the relationship between Bidask spread and earnings management. A study by [14] shows that corporate governance moderates the effect of bid-ask spreads on earnings management.

Based on the agency theory of [32], earning management can be minimized with GCG. GCG can control actions that agents should not carry out. Research by [3] shows that corporate governance can dampen the effects of the bid-ask spread on earnings management. Companies require the implementation of corporate governance to prevent revenue management practices. Investors can also consider corporate governance before making investment decisions. This study aligns with [8] that corporate governance can moderate the impact of the bid-ask spread on earnings management. Studies by [23] also show that corporate governance can mitigate information asymmetries on earning management. A company that is still weak in implementing corporate governance can create opportunities for several parties to maximize their interests. With excellent and correct corporate governance can avoid excessive revenue management. The implementation of GCG is urgently required for the company as a reference for a transparent, efficient, and legally compliant market. The performance of corporate governance with applicable principles and guidelines can minimize information inequality in the company [33].

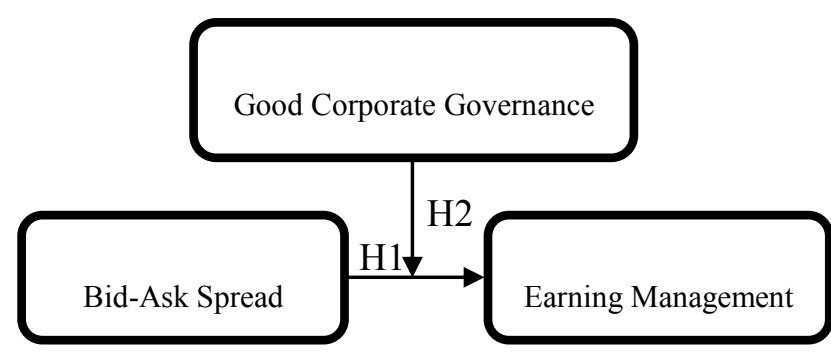

Fig. 1: Research Model

GCG can control irregularities that agents shouldn't. CGPI is a research and rating program organized by IICG to implement GCG in Indonesia in listed companies. The CGPI rating is carried out to improve the quality of executing the GCG principles by listed companies in Indonesia. The IICG ranking of the scores of listed companies aims to positively influence the future of the company. FCGI believes 
that implementing GCG can achieve several benefits, namely: (1) facilitating the capital increase, (2) reducing the cost of capital, (3) improving economic and business performance,

Determining share prices [34].

H2: GCG weakens the relationship between the bidask spread and earning management.

\section{Method}

The type of data in this study is quantitative data in the form of numbers in the annual report, stock prices, and research from IICG in the form of Corporate Governance Perception Index (CGPI) scores. The data source used in this study is secondary data from the annual financial statements of banking companies for 2014-2020. The data source in this study is the annual financial statements listed in the (IDX) for the period 20142020 and taken from www.IDX.co.id. The bid-ask data is from Yahoo Financial in the historical data section. Then you can access the CGPI rating data by contacting the Indonesian Institute of Corporate Governance (IICG) office or SWA magazine www.swa.co.id. The examination of the influence of the variable GCG in the connection between information asymmetry and earning management is carried out with the help of a regression equation through an interaction test, moderated regression analysis (MRA). According to [35], MRA is a particular application of multiple linear regression that includes interactive elements in the regression equation (multiplication of two or more independent variables). The following table describes the operating variables used in this study, as shown in Table 1.

Table 1. Definition of Operational Variables

\begin{tabular}{|c|c|c|c|}
\hline Variable & Proxy & Scale & Source \\
\hline $\begin{array}{c}\text { Earning } \\
\text { Management }\end{array}$ & 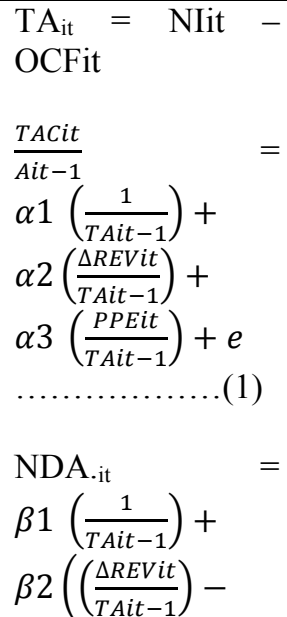 & Ratio & [3] \\
\hline
\end{tabular}

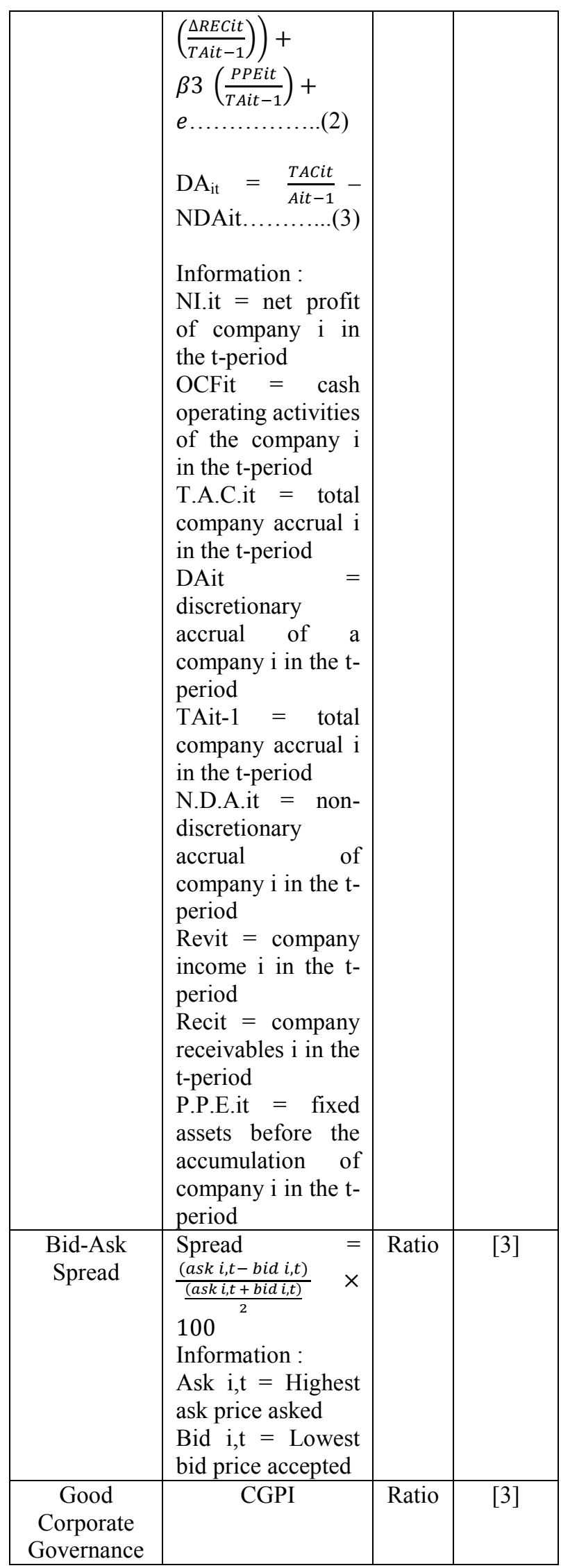

Source: data that has been processed, (2021)

Based on several specified criteria, the sampling method used is targeted sampling. The sample is 
based on the following criteria [3]; a) Go to public banking companies listed in the IDX. b) The model company has published an annual report for the 2014-2020 financial year. c) The example company has year-end bid and ask data, so there are 17 banks with annual report observations for 2014-2020, so there are 102 observations. Below are the sampling criteria for banking companies in the IDX for the period 2014-2020. The sampling criteria used are as follows:

Table 2. Data Sample

\begin{tabular}{|c|c|c|}
\hline No. & Sample Criteria & Total \\
\hline 1. & $\begin{array}{l}\text { Banking companies listed on the } \\
\text { Indonesia Stock Exchange (IDX) for } \\
\text { the period 2014-2020 }\end{array}$ & 46 \\
\hline 2. & $\begin{array}{l}\text { Banking companies that do not } \\
\text { follow the CGPI assessment by IICG } \\
\text { in 2014-2020 }\end{array}$ & (29) \\
\hline 3. & $\begin{array}{l}\text { Banking companies that do not use } \\
\text { rupiah in their financial statements } \\
\text { for } 2014-2020\end{array}$ & (0) \\
\hline \multicolumn{2}{|r|}{ Number of Research Samples } & 17 \\
\hline \multirow{2}{*}{\multicolumn{2}{|c|}{ Observation Year }} & 6 \\
\hline & & 102 \\
\hline
\end{tabular}

Source: data that has been processed, (2021)

\section{Result and Discussion}

The results of this study displayed are secondary data processed using the Warp-PLS 6.0 program. Carried out the results for testing on 102 samples with the following results:

Table 3. Model Fit

\begin{tabular}{|c|c|c|c|}
\hline Criteria & Cut of Value & Results & Evaluation \\
\hline $\begin{array}{c}\text { Average Path } \\
\text { Coefficient } \\
\text { (APC) }\end{array}$ & $\mathrm{P}=0.001$ & 0.232 & Fit Model \\
\hline $\begin{array}{c}\text { Average R- } \\
\text { Squared (ARS) }\end{array}$ & $\mathrm{P}<0.001$ & 0.367 & Fit Model \\
\hline $\begin{array}{c}\text { Average } \\
\text { Adjusted R- } \\
\text { Squared } \\
\text { (AARS) }\end{array}$ & $\mathrm{P}<0.001$ & 0.317 & Fit Model \\
\hline $\begin{array}{c}\text { Average block } \\
\text { VIF (AVIF) }\end{array}$ & $\begin{array}{c}\text { acceptable if } \\
<=5, \text { ideally } \\
<=3.3\end{array}$ & 1.084 & Fit Model \\
\hline $\begin{array}{c}\text { Average Full } \\
\text { Collinearity } \\
\text { VIF (AFVIF) }\end{array}$ & $\begin{array}{c}\text { acceptable if } \\
<=5, \text { ideally } \\
<=3.3\end{array}$ & 1.327 & Fit Model \\
\hline $\begin{array}{c}\text { Tenenhaus GoF } \\
\text { (GoF) }\end{array}$ & $\begin{array}{c}\text { small }>=0.1, \\
\text { medium }>= \\
0.25, \text { large } \\
>=0.36\end{array}$ & 0.409 & Fit Model \\
\hline Sympson's & $\begin{array}{c}\text { acceptable if } \\
>=0.7,\end{array}$ & 0.858 & Fit Model \\
paradox ratio & & \\
\hline \multicolumn{3}{|c|}{}
\end{tabular}

\begin{tabular}{|c|c|c|c|}
\hline (SPR) & ideally $=1$ & & \\
\hline $\begin{array}{c}\text { R-squared } \\
\text { contribution } \\
\text { ratio (RSCR) }\end{array}$ & $\begin{array}{c}\text { acceptable if } \\
>=0.9, \\
\text { ideally }=1\end{array}$ & 0.974 & Fit Model \\
\hline $\begin{array}{c}\text { Statistical } \\
\text { suppression } \\
\text { ratio (SSR) }\end{array}$ & $\begin{array}{c}\text { acceptable if } \\
>=0.7\end{array}$ & 0.751 & Fit Model \\
\hline $\begin{array}{c}\text { Nonlinear } \\
\text { bivariate } \\
\text { causality } \\
\text { direction ratio } \\
\text { (NLBCDR) }\end{array}$ & $\begin{array}{c}\text { acceptable if } \\
>=0.7\end{array}$ & 0.778 & Fit Model \\
\hline
\end{tabular}

Source: Warp-PLS 6.0 output processed, (2021)

Table 3 shows the model fit indicators, which can conclude that the model has a good fit, where the P-value for the Average path coefficient (APC) is 0.232 , so the APC value meets the model fit. Average R-squared (ARS) and average adjusted Rsquared (AARS). Which means the model fit. The resulting average block VIF (AVIF), Average full collinearity VIF (AFVIF) meet less than 5. This means that the research data is declared fit and does not have multicollinearity problems between indicators. The resulting Tanenhaus GoF (GoF) is $0.409>0.36$, which means the model is good. Sympson's paradox ratio (SPR) and R-squared contribution ratio (RSCR) produce a value equal to 1 , which means there is no causality problem in the model. Meanwhile, the Statistical suppression ratio (SSR) and Nonlinear bivariate causality direction ratio (NLBCDR) resulted in a value of $0.778<0.7$, which means weak causality.

Table 4. Descriptive Statistics

\begin{tabular}{|c|c|c|c|c|c|}
\hline & $\mathrm{N}$ & Min & Max & Mean & $\begin{array}{c}\text { Std. } \\
\text { Dev }\end{array}$ \\
\hline BAS & 102 & .000 & 14.271 & 2.466 & 2.382 \\
\hline EM & 102 & -.678 & 2.436 & -.186 & .647 \\
\hline GCG & 102 & 85.750 & 94.860 & 8.784 & 2.327 \\
\hline $\begin{array}{c}\text { Valid N } \\
\text { (listwise) }\end{array}$ & 102 & & & & \\
\hline
\end{tabular}

Source: SPSS output, (2021)

Table 5. Path Coefficient

\begin{tabular}{|c|c|c|c|}
\hline Variable & $\begin{array}{c}\text { Path } \\
\text { Coefficients }\end{array}$ & P-Value & Result \\
\hline BAS & 0.406 & 0.003 & Effect \\
\hline GCG* BAS $^{*}$ & -0.239 & 0.060 & No effect \\
\hline
\end{tabular}

Source: Warp-PLS 6.0 output processed

Table 6. Hypothesis Testing Results

\begin{tabular}{|c|c|c|c|c|}
\hline $\mathrm{H}$ & $\begin{array}{c}\text { Hypothesis } \\
\text { Description }\end{array}$ & $\begin{array}{c}\text { Path } \\
\text { Coeff } \\
\text { icient } \\
\text { Value }\end{array}$ & $\begin{array}{c}\text { P- } \\
\text { Value }\end{array}$ & Decision \\
\hline H1 & Bid-ask spread has a & 0.406 & 0.003 & Accepted \\
\hline
\end{tabular}




\begin{tabular}{|c|c|c|c|c|}
\hline & $\begin{array}{l}\text { significant positive } \\
\text { effect on earnings } \\
\text { management }\end{array}$ & & & \\
\hline $\mathrm{H} 2$ & $\begin{array}{l}\text { Corporate } \\
\text { governance } \\
\text { moderates the effect } \\
\text { of bid-ask spread on } \\
\text { earnings } \\
\text { management. }\end{array}$ & $\begin{array}{c}- \\
0.239\end{array}$ & 0.060 & Rejected \\
\hline
\end{tabular}

Source: Warp-PLS 6.0 output processed, (2021)

\subsection{Bid-ask Spread on Earning Management}

The hypothesis test results result in a p-value of 0.003 so that the variable bid-ask spread has a significant influence on earnings management. The first hypothesis of this study is rejected because a large spread increases the manager's ability to manage earnings. Large spreads can indicate an information imbalance between internal and external parties. Managers easily control profits out of their interest or are pressured to perform well in the company because external parties themselves do not know its condition and prospects. The results of this study are consistent with the research carried out [3] also showed a negative correlation between bid-ask spreads as a proxy for information asymmetry in earnings management.

The low prevalence of thinning transactions on the stock exchange, reinforced by the OJK capital market statistics 2018. This shows the value compared with the number of public offers in 2017 and 2018, averages 252.6 and 283.2. Asymmetrical relationships, which rely more on equity than debt financing. The information asymmetry does not influence earnings management due to the possibility of good economic growth and the potential of financial reporting based on qualitative principles. Studies support the results of this study by [8], [9], [13].

The presence of a bid-ask spread can encourage managers to provide information that is not occurring. The results of this study are also supported by previous research, namely research by [2], [10], that information asymmetry affects earning management. This aligns with the [11] study, which shows that information asymmetry positively impacts revenue management practices. Agency theory implies that information asymmetries exist between managers to take earning management measures aimed at acting opportunistically, namely to maximize personal profit. From this, can conclude that information asymmetry has a positive correlation and impacts earning management. In other words, if the bid-ask spread is high, it can affect earnings management practices.
The first hypothesis in this study is accepted because when the spread is large, the more excellent the opportunity for managers to carry out earnings management. Large spreads can indicate an imbalance of information ownership between internal parties and external parties. Because external parties do not know the state and prospects of the company in the future, managers can easily carry out earnings management for their interests or because of the urge to show good performance. Managers manage earnings as much as possible to achieve performance targets and compensation bonuses, reduce the possibility of violating debt covenants, and reduce political costs. However, due to the intervention of parliament, it can minimize management's flexibility to manage earnings by providing better and better information to outsiders. The quality of the financial statements will show the company's earnings management level; this will show a large spread. Therefore, when the spread on the company is large, it will increase the manager's opportunity to carry out earnings management.

\subsection{Good Corporate Governance Moderates Bid-Ask Spread on Earning Management}

The results of testing the second hypothesis show that corporate governance cannot moderate the effect of the bid-ask spread on earning management. So, can conclude that the second hypothesis of this study was rejected. The results of this study are by the research of [3]. The purpose of implementing GCG is to reduce agency problems. Agency problems can occur because there is a conflict of interest between the agent and the principal. The agent wants to fulfill his interests but must also improve the welfare of the principal. These differences in interests can motivate earnings management practices. The implementation of good corporate governance is expected to reduce the opportunism of managers in managing the company. Managers' opportunistic behavior is born from a conflict of interest between managers as agents and stakeholders as principals. There is a tendency for managers to behave in moral hazard to avoid risk by utilizing information imbalance (information asymmetry). Applying the principles of good corporate governance consisting of transparency, accountability, responsibility, and fairness is expected to safeguard the interests of various parties within the company, including losses to outsiders due to the manager's opportunistic behavior. So, even though the spread is large and there is an opportunity to carry out earnings management, the possibility of opportunistic behaviour can be suppressed by GCG. 
This is because IICG and SWA the magazine announced the previous year's survey results in the following year. Therefore, the results of the CGPI assessment are less than optimal in the year they should be. IICG and SWA announce information related to GCG. The CGPI score can cause this to happen because the CGPI score from the survey from the IICG does not reflect the actual corporate governance in the relevant year. Thus, the results of the CGPI assessment are less than optimal in the year they should be. The occurrence of conflicts between owners and managers of the company can be reduced to a control mechanism that can harmonize the interests of a company. The results of this study are by [11] that GCG cannot moderate the relationship between bid-ask spreads on earnings management. According to agency theory, the application of GCG is believed to moderate the effect of the bid-ask spread on earnings management. According to agency theory, can be minimized earnings management actions by implementing GCG by aligning the interests of various parties. The trick is to increase supervision of management performance and accountability to reduce the level of earnings management.

The delay in submitting information related to GCG can be interpreted that the GCG index does not affect the possibility of management to carry out earnings management. Therefore, the implementation of GCG does not reduce the level of corporate earnings management. Although the study results show that GCG cannot weaken the effect of bid-ask spreads on earnings management, corporate stakeholders should consider implementing GCG to control and prevent earnings management actions. Information related to GCG announced by IICG and SWA magazine is one of the signals given by the company to reduce the occurrence of information asymmetry. Can use it to make decisions in the capital market. The delay in delivering information related to GCG shows that the GCG index does not affect the possibility of management to carry out earnings management. Therefore, the implementation of GCG does not reduce the company's earnings management level. The results of this study indicate that although GCG cannot weaken the effect of bid-ask spread on earnings management, corporate stakeholders should consider the application of GCG as an effort to control and prevent earnings management actions. However, the hypothesis in this study was rejected.

\section{Conclusion}

Based on the results of hypothesis testing, it can be concluded as follows: (1) Bid-ask spread has a positive effect on earnings management. So, if investors want to make investment decisions and if investors want to see if there are indications of earnings management in the company. Investors can consider it by looking at and analyzing the value of the bid-ask spread. (2) GCG cannot moderate the effect of bid-ask spread on earnings management. Applying good rules is needed to prevent opportunities for earnings management practices, such as strengthening and implementing internal control systems. Investors can also consider corporate governance factors before making investment decisions. This study has several limitations, such as the variables used are limited to only one independent variable with one moderating variable. In addition, the sample of this study is limited because it uses the CGPI proxy. Conflicts between owners and managers of the company can be reduced to a control mechanism that can harmonize various interests within the company.

Based on the research results and conclusions, can give various recommendations. Suggestions for further research are to expand and increase the number of research samples by extending the research period. Furthermore, using proxies other than CGPI to measure corporate governance variables. The number of companies participating in the research/CGPI rating is minimal, and adding other variables can affect earnings management. Investors are advised to pay attention to the supporting factors, namely, to continue implementing better corporate governance in the company every year before investing. In future research, can use other proxies to measure earnings management, namely accrual earnings management.

\section{Acknowledgment:}

This research was funded by the World Class Research Diponegoro University, Grant No. 11801/UN7.6.1/PP/2021 for the 2021 and 2022 fiscal years.

\section{References:}

[1] S. D. Utomo, Z. Machmuddah, and I. D. Pamungkas, "The effect of litigation risk and audit quality on earning management: Evidence in Indonesia," WSEAS Trans. Bus. Econ., vol. 16, 2019.

[2] V. Natasha and N. Bangun, "Pengaruh Bid Ask Spread, Leverage, Dan Firm Size Terhadap Earning Management," J. Paradig. Akunt., vol. 2, no. 2, pp. 863-872, 2020. 
[3] O. Agatha and E. Imelda, "Pengaruh Bid Ask Spread Terhadap Earning Management Dimoderasi Corporate Governance," $J$. Multiparadigma Akunt. Tarumanegara, vol. 2, no. 2018, pp. 1781-1790, 2020.

[4] M. C. Jensen and W. H. Meckling, "Theory of the Firm: Managerial Behavior, Agency Costs, and Ownership Structure," 2016 Value Summit Power VE, 1976.

[5] E. S. Mardjono, Y. S. Chen, and L. J. He, "Earning management and the effect characteristics of audit committee, independent commissioners: Evidence from Indonesia," Int. J. Bus. Soc., vol. 21, no. 2, pp. 569-587, 2020, DOI: 10.5430/rwe.v11n3p108.

[6] C. Indonesia, "Bank Syariah Mandiri Diduga Beri Pembiayaan Fiktif Rp1,1 T Baca artikel CNN Indonesia 'Bank Syariah Mandiri Diduga Beri Pembiayaan Fiktif Rp1,1 T' selengkapnya di sini: https://www.cnnindonesia.com/ekonomi/201 80214172620-78-276222/bank-syariahmandiri-did," 2018. https://www.cnnindonesia.com/ekonomi/201 80214172620-78-276222/bank-syariahmandiri-diduga-beri-pembiayaan-fiktif-rp11t.

[7] Kompas.com, "Laporan Keuangan Bukopin 'Tersandung' Kasus Kartu Kredit, Ini Penjelasan Dirut Artikel ini telah tayang di Kompas.com dengan judul 'Laporan Keuangan Bukopin "Tersandung" Kasus Kartu Kredit, Ini Penjelasan Dirut', Klik untuk baca: https://ekonomi.kompas.co," 2018.

https://ekonomi.kompas.com/read/2018/05/0 3/070000026/laporan-keuangan-bukopintersandung-kasus-kartu-kredit-inipenjelasan-dirut?page $=$ all.

[8] N. Bangun and R. Monoarfa, "Effect of Corporate Governance, Information Asymmetry, And Firm Size on Earning Management.," Ilkogr. Online, vol. 20, no. 3, 2021.

[9] R. I. Sunaryo and D. Saripujiana, "The effects of information asymmetry, earning management, voluntary disclosure and market value of equity on cost of equity capital," J. Econ. Business, Account. Ventur., vol. 21, no. 1, pp. 79-88, 2018.

[10] N. Bangun, "Effect of Bid-Ask Spread, Profitability, and Free Cash Flow on Earning Management," J. Akunt., vol. 23, no. 3, pp. 449-467, 2019.
[11] Y. K. W. Putri and I. K. Sujana, "The influence of bid-ask spread and leverage on earnings management with good corporate governance as moderating variable," Int. Res. J. Manag. IT Soc. Sci., vol. 5, no. 3, pp. 821, 2018.

[12] A. Ajina, M. Bouchareb, D. Sougné, And A. Habib, "The Effect of Earnings Management on Bid-Ask Spread and Market Liquidity," 2017.

[13] E. Evodila, E. Erlina, and A. Kholis, "The Effect of Information Asymmetry, Financial Performance, Financial Leverage, Managerial Ownership on Earnings Management with the Audit Committee as Moderation Variables," J. Mantik, vol. 4, no. 3, pp. 1734-1745, 2020.

[14] H. P. Harahap, "The influence of information asymmetry on earnings management with Good Corporate Governance (GCG) as the moderating variable," Indones. Account. Rev., vol. 7, no. 1, pp. 61-68, 2018.

[15] E. Trisnawati and J. Gunawan, "Governance disclosures, senior management and their influences on tax avoidance," Int. J. Innov. Creat. Chang., vol. 9, no. 3, pp. 85-104, 2019.

[16] P. Wasan and K. Mulchandani, "Corporate governance factors as predictors of earnings management," J. Gen. Manag., vol. 45, no. 2, pp. 71-92, 2020, DOI: $10.1177 / 0306307019872304$.

[17] T. Nguyen, S. Locke, and K. Reddy, "A dynamic estimation of governance structures and financial performance for Singaporean companies," Econ. Model., vol. 40, pp. 1-11, 2014, DOI: 10.1016/j.econmod.2014.03.013.

[18] M. B. Lozano, B. Martínez, and J. Pindado, "Corporate governance, ownership and firm value: Drivers of ownership as a good corporate governance mechanism," Int. Bus. Rev., vol. 25, no. 6, pp. 1333-1343, 2016, doi: 10.1016/j.ibusrev.2016.04.005.

[19] M. P. Sari, Kiswanto, L. V. Rahmadani, H. Khairunnisa, and I. D. Pamungkas, "Detection fraudulent financial reporting and corporate governance mechanisms using fraud diamond theory of the property and construction sectors in Indonesia," Humanit. Soc. Sci. Rev., vol. 8, no. 3, pp. 1065-1072, 2020, DOI: 10.18510/HSSR.2020.83109.

[20] M. Chabachib, H. Hersugondo, D. Septiviardi, and I. D. Pamungkas, "The effect of investment opportunity set and company growth on firm value: Capital 
structure as an intervening variable," Int. J. Innov. Creat. Chang., vol. 12, no. 11, pp. 139-156, 2020.

[21] H. S. Rukmana, "Pentagon Fraud Affect on Financial Statement Fraud and Firm Value," South East Asia J. Contemp. Bus., vol. 16, no. 5, pp. 118-122, 2018.

[22] D. A. Cohen and P. Zarowin, "Accrual-based and real earnings management activities around seasoned equity offerings," $J$. Account. Econ., vol. 50, no. 1, pp. 2-19, 2010, DOI: 10.1016/j.jacceco.2010.01.002.

[23] S. A. Irwandi, I. Ghozali, Faisal, and I. D. Pamungkas, "Detection fraudulent financial statement: Beneish m-score model," WSEAS Trans. Bus. Econ., vol. 16, no. May, pp. 271-281, 2019.

[24] A. Michaels and M. Grüning, "Relationship of corporate social responsibility disclosure on information asymmetry and the cost of capital," J. Manag. Control, 2017, DOI: 10.1007/s00187-017-0251-z.

[25] H. Sidanti and A. Istikhomah, "The Effect Of Stock Price, Share Return, Share Trading Volume, And Return Variant On Bid-Ask Spread On Textile And Garment Companies Listed On The Indonesia Stock Exchange, 2019-2020," Int. J. Sci. Technol. Manag., vol. 2, no. 4, pp. 1357-1366, 2021.

[26] V. J. Richardson, "Information Asymmetry and Earnings Management," J. Univ. Kansas, 1998.

[27] K. Kiswanto and N. Fitriani, "The influence of earnings management and asymmetry information on the cost of equity capital moderated by disclosure level," J. Kuang. and Perbank., vol. 23, no. 1, pp. 123-137, 2019.

[28] B. D. Handayani, A. Rohman, A. Chariri, and I. D. Pamungkas, "Corporate financial performance on corporate governance mechanism and corporate value: Evidence from Indonesia," Montenegrin J. Econ., vol. 16, no. 3, pp. 161-171, 2020, doi: 10.14254/1800-5845/2020.16-3.13.

[29] J. Widiatmoko, M. G. K. Indarti, and I. D. Pamungkas, "Corporate governance on intellectual capital disclosure and market capitalization," Cogent Bus. Manag., vol. 7, no. 1 , pp. $0-14,2020$, DOI: 10.1080/23311975.2020.1750332.

[30] R. Hidayat, S. Wahyudi, H. Muharam, and F. Zainudin, "Institutional ownership, productivity sustainable investment based on financial constraints and firm value:
Implications of agency theory, signaling theory, and asymmetry information on sharia companies in Indonesia," Int. J. Financ. Res., vol. 11 , no. 1 , pp. $71-81,2020$, DOI: 10.5430/ijfr.v11n1p71.

[31] H. Wiharno and D. S. Rahayu, "Determinants of Bid-Ask Spread in Indonesia: More Evidence from LQ45," Indones. J. Bus. Econ., vol. 1, no. 1, 2018.

[32] M. C. Jensen and W. H. Meckling, "Theory of the Firm: Managerial," J. financ. econ., vol. 3, pp. 305-360, 1976, DOI: http://dx.doi.org/10.1016/0304405X(76)90026-X.

[33] I. D. Pamungkas and S. D. Utomo, "Fraudulent Financial Reporting: An Application of Fraud Pentagon Theory to Association of Southeast Asian Nations Corporate Governance Scorecard," Journal of Advanced Research in Law and Economics 9 (5 (35)). pp. 1729-1737, 2018.

[34] I. Muda, W. Maulana, H. Sakti Siregar, and N. Indra, "The analysis of effects of good corporate governance on earnings management in Indonesia with panel data approach," Iran. Econ. Rev., vol. 22, no. 2, pp. 599-625, 2018.

[35] S. A. Irwandi and I. D. Pamungkas, "Determinants of financial reporting quality: Evidence from Indonesia," J. Int. Stud., vol. 13, no. 2, pp. 25-33, 2020, DOI: $10.14254 / 2071-8330.2020 / 13-2 / 2$.

\section{Contribution of Individual Authors to the Creation of a Scientific Article (Ghostwriting Policy)}

Imam Ghozali find research ideas.

Sugeng Wahyudi focus on phenomena and research GAP.

Hersugondo analyzing data.

Abdul Karim collecting data.

Anton Satria Prabuwono method, translating and proofreading article.

Imang Dapit Pamungkas Corresponding Author, Submit article, Mendeley references and Revision article.

\section{Creative Commons Attribution License 4.0 (Attribution 4.0 International, CC BY 4.0)}

This article is published under the terms of the Creative Commons Attribution License 4.0 https://creativecommons.org/licenses/by/4.0/deed.en US 